\title{
伸長結晶とゴム物性 \\ 第1回 一軸延伸と伸長結晶性
}

\section{土 岐 重 之}

\section{Strain-Induced Crystallization and Mechanical Properties of Rubber. 1. Uniaxial Deformation and Strain-Induced Crystallization of Rubbers}

\author{
Shigeyuki TOKI (Retired from Mahidol University, State University of New York at Stony Brook, Tonen Chemical and \\ Bridgestone.) shigeyukitoki@gmail.com
}

Strain-induced crystallization (SIC) of rubber is a self-reinforcing mechanism of rubber. The phenomenon was found in 1925, however, the elucidation of it has been a controversial topic since then. In 2002, synchrotron X-ray made it possible to measure stress-strain relation and SIC simultaneously. In 2012, the time constant of SIC is revealed as less than $60 \mathrm{~m}$-sec by very fast experimental facilities. SIC is created instantaneously compared to practical deformation processes.

1. SIC is a common phenomenon of rubber and rubber compounds because several rubbers such as natural rubber (NR), synthetic polyisoprene rubber (IR), butadiene rubber (BR), butyl rubber (IIR), chloroprene rubber (CR), thermoplastic elastomer (TPE) and reinforcement filled rubber perform SIC.

2. During deformation, rubber perform several phenomena such as SIC with temperature upturn, cavitation due to void or crack, creation of radical due to breakdown of network, stress softening and hardening, and limited extensibility of chains between crosslinks simultaneously. Therefore, we should distinguish each phenomenon and analyze the contributions of them to a whole rubber performance.

3. Rubber is in-homogeneous material. Synthetic rubbers may include $2-10 \%$ of hard gel, remained catalysis and anti-oxidants. Natural rubber include about $6 \%$ of non-rubber components such as protein, carbohydrate, phospholipids, metal ions and others. Sulfur vulcanization system add zinc oxide and stearic acids as catalysts. Some of carbohydrates, zinc oxide and stearic acids are crystal. Protein aggregates, phospholipids and fatty-acids micelles are non-crystalline solid materials. Those solid materials may cause stress or strain concentrated points because solid particles are unable to be deformed in liquid-like matrix. Vulcanization is a chemical reaction of solid particle such as sulfur and catalysts with polymer chains in high viscous matrix. Therefore, crosslinks are unable to be distributed homogeneously. These heterogeneity may play important role for SIC of rubber.

Key Words : Crystallization, Mechanical Properties, Rubber

\section{1.は じ め に}

伸長結晶性は多くのゴム，（天然ゴム $(\mathrm{NR})$ ，合成ポリ イソプレンゴム (IR), ブチルゴム (IIR), ブタジェンゴ ム $(\mathrm{BR})$, クロロプレンゴム $(\mathrm{CR})$, 熱可塑性エラストマ 一 (TPE), 充填剤を混ぜたゴム (Filled Rubber $))$ で,

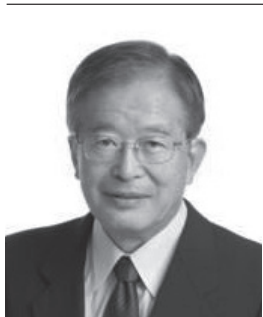

土岐 重之；土岐技術士事務所。（ ～180-0001 東京都武蔵野市吉祥寺北町 2-7-12) Ph. D., 技術 士. 昭和 42 年, 東京都立大学物理科博士課程 中退, 同年, ブリヂストン入社. 昭和 56 年, テネシー大学高分子工学科 $\mathrm{Ph}$. D, 昭和 62 年, 東燃化学入社, 昭和 63 年, アクロン大学高分 子工学科, 平成 12 年, ニューヨーク州立大学 ストーニーブロック校, 平成 25 年, マヒドン 大学. 専門は, 高分子物性, 高分子加工. 
観測されているので，ゴムの一般的な特徵である。（全く 結晶化しないSBRはむしろ例外)，Tgが室温より十分低 く, 単純な分子構造をもつ鎖状高分子は, 大変形まで伸長 すると結晶を造る可能性が高い. 補強剤を配合したゴム は, 純ゴム以上の伸長結晶を示すので, 過酷な使用条件で 使われる実用ゴム配合物の物性向上に寄与している。伸長 結晶化はゴムの自己補強メカニズムであり, 不均質なゴム の応力集中点からの破壊を防いで, ゴムの高い伸長度, 破 壊強度, 引き裂き強度をもたらしている。但し, 伸長結晶 と補強メカニズムについては, 多くの点で論争が続いてい る。例えば

(1). 伸長結晶が一軸伸長の条件下で, 大変形での応力の立 ち上がりに寄与するか. Floryは，「伸長結晶化は応力を 下げるが生成された伸長結晶は大きな網目点となり応力を 上げる」とした。一方 Treloar は伸長結晶が始まる歪みと 応力が立ち上がる歪みが異なる事と, 非ガウス鎖の伸び切 り効果で応力一歪み関係を完全にシミュレートできるので 「伸長結晶は応力に殆ど寄与しない」とした.

(2). 伸長結晶化のプロセスは「伸長と, 配向の増加による エントロピー減少が結晶の融点 $(T m)$ の上昇をもたらし, アモルファスから結晶への相変化が生じる」とFloryは説 明したが，平衡を仮定した静的な熱力学である，実際に は, 伸長と共に歪みが大きくなっており, 平衡条件での結 晶生成ではない. 動的条件に対応して, 伸びたアモルファ スの収縮力や, 結晶表面を造りだすエンタルピー等を考慮 した新しい熱力学が求められている.

(3). 分子鎖を伸長し, 配向させ, 結晶化をもたらすには力 の支点が必要である．網目点が網目点間の分子を引っ張 り, 弾性的に変形させる支点と仮定されてきた。 ところ が, 伸長結晶を始める歪みは網目密度を変えても変化しな い. 更に, 網目のない未加硫ゴムも伸長結晶を示すので, 粘性を与える絡み合い点を支点と考えるべきと提案されて いる.

(4). 結晶構造が物性に直接寄与するわけではなく, 結晶の 集合体である微結晶の形態, 大きさが物性に寄与する。伸 長結晶は折り畳み結晶で作られている微結晶なのか, 伸び 切り鎖結晶（シシカバブのシシ）の微結晶なのか. この選 択は伸長結晶の生成過程にも関係しており, 議論が始まっ たばかりである.

この論文では, 現在の到達点を示し, 残されている論争 点を明らかにして, 課題を提示したい.

\subsection{Goughの実験}

1806 年 Gough がゴム物性の特徵を定性的に明らかにす る3つの有名な実験を報告した。加硫はまだ発明されてお らず，実験に用いたゴムはラテックスを乾燥した生ゴムで ある. 盲目の天才 Goughの実験は熱力学の発展に大きく 寄与したが, 解釈は原子論さえ登場していない時代のもの
なので誤っており, 修正された. 現在の科学に基づいた解 釈を記す。

第 1 の実験. ゴムを急速に引っ張るとゴムの温度が上昇す る. 現在の解釈 : 伸長による大変形で伸長結晶が生じ, 結 晶生成による発熱が $10^{\circ} \mathrm{C}$ 近くの温度上昇をもたらす。工 ントロピー減少による温度上昇は $0.1^{\circ} \mathrm{C}$ 程度であって検知 は難しい.

第2の実験. ゴムに荷重をかけて伸ばしておいて, 温度を 上げると収縮が起きる. 現在の解釈 : 温度上昇による張力 の増加は, Kelvin, Jouleが発達させた熱力学により定義 されたエントロピー弾性の寄与である. ゴム分子のミクロ ブラウニアン運動がエントロピー弾性の源であり, 気体分 子の運動と対応して議論された。

第3の実験. ゴムを伸長して冷水に入れると, 放しても収 縮せず伸長したままになる。取り出して熱湯をかけると収 縮してゴムに戻る. 現在の解釈 : 伸長結晶の生成とその融 解現象である.

$3 つ の$ 実験は, 伸長結晶がゴム物性の大きな特徵である ことを示している ${ }^{1-7)}$.

\section{2 Katzの広角 X線写真.}

1925 年 Katzが未加硫と加硫の天然ゴムを，4倍程度伸 長して 10 数時間の露光で広角 X線写真を撮り, セルロー スや絹と同じ繊維困形を得た。 X線を用いた結晶の解析は 1912 年にLaue, Bragg父子が始めたばかりだったので写 真は不鮮明だが，ゴム物性の特徵は伸長結晶ですべて説明 できるとした. 1932年, StaudingerはX線写真から結晶 格子の存在, すなわち, 繰り返し単位の存在が証明された ことと, 粘度測定からの分子量の大きさに基づいて, 高分 子説を確立した. 1930 年代, 40 年代には加硫と未加硫天 然ゴムのX線測定が数多く報告されている. 未加硫天然ゴ ムをゲル（溶媒不可溶成分）とゾル（溶媒可溶成分）に分 け，ゾルでも伸長結晶を示すという報告もされている ${ }^{8,9)}$. 歪みの増加と共に結晶化度が増加する事を Mitchellが精密 に解析した ${ }^{10)}$ 。通常のX線装置の台上に引つ張り試験機を 置き, 伸長による応力の上昇と結晶の 120 面の $X$ 線散乱強 度の変化が同時に測定された。結晶によるX線散乱強度は 引っ張り過程で歪みと共に増大し, 応力の増加と連動し た. 収縮過程では応力が減少するがX線散乱強度は伸長過 程より大きく, 伸長過程と収縮過程で応力が等しくなる歪 みとX 線散乱強度が最小になる歪みはほほ等しかった ${ }^{11,12)}$.

\section{3 シンクロトロン放射光を用いた広角 X線写真.}

2002 年シンクロトロン放射光を用いたX線によって露光 時間が短縮され秒単位で写真を撮れるようになり, 引っ張り 試験機を用いて応力 - 歪み関係とWAXD写真を同時測定す ることが可能になった. 歪み速度は $0.007-0.35 \mathrm{sec}^{-1}$ 13-16). 2012 年シンクロトロンX 線の強度, CCD カラの感度, 引っ張り試験機の歪み速度が上がり, 歪み速度 $40 \mathrm{sec}^{-1}$, 


\section{NR $-50^{\circ} \mathrm{C}$, Strain 6}

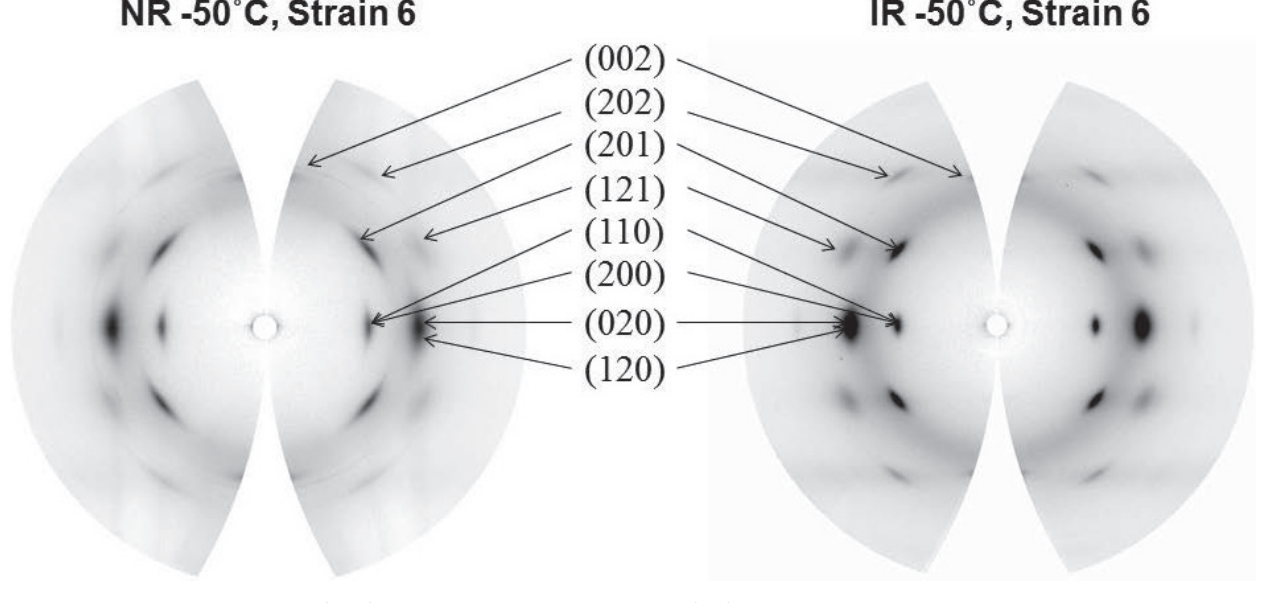

図 1 未加硫の天然ゴム (NR) と合成ポリイソプレン (IR) の- $50^{\circ} \mathrm{C}$ での伸長結晶の広角 $\mathrm{X}$ 線回析写 真 ${ }^{19)}$. Reprinted with permission from Macromolecules 2013, 45, 4520-4528. Copyright 2013 American Chemical Society

露光時間 $20 \mathrm{msec}$ でX線散乱強度分布を測定可能になった. 伸長結晶化の 8 割は時定数が $10-100 \mathrm{msec}$ であることが 判った. 時定数が長い結晶化も数秒以内に完了する ${ }^{17)}$. す でに 1968 年 Mitchellが熱電対を埋め込んだゴムを急速伸 長し，温度上昇から結晶化が始まる時間を計算して得た 值，(60 msec） と一致した ${ }^{18)}$. 伸長結晶は変形が設定し た歪みに達したら，伸長に要する時間に比べると，瞬時に (Instantaneously) 生じる.

NR とIRの伸長結晶のWAXD写真を示す（図 1)。結晶 パターンをきれいに撮るために, NRはラテックスの水分 を蒸発させて作ったシート, IRはNR対応グレードの IR2200をトルエンに溶かし，トルエンを蒸発させてシー トを作った. シートからダンベルを切り出し, 引っ張り試 験機で $-50^{\circ} \mathrm{C}$ の恒温槽の中で歪み速度 $0.007 \mathrm{sec}^{-1}$ で $600 \%$ まで引っ張って $30 \mathrm{sec} の$ 露光時間で撮影した. 静的結晶を - 50ㄷ C゙作るには 1 か月以上かかるので, これは純粋なゴ ム分子の伸長結晶である. 加硫したNRと IRのゴムを室温 で測定しても，スポットの位置が完全に等しいので，結晶 格子は同じである。加硫してもしなくても，NRであろう とIRであろうと，シスポリイソプレンの結晶を観測して いるのだから等しい。 二つの写真を比較すると，スポット の大きさがIRの方が小さく濃い. IRの方が結晶の完全性 が良いことを示している，後述するが，我々の計算による とNRの方がIRより配向度が低く, 結晶の欠陥も多い.こ れらの傾向は加硫ゴムを室温で引っ張っても全く同様であ る. 伸長結晶が始まる歪みはNRの方が小さいのでNRの 方が結晶化はしやすいが，結晶の完全性は低い ${ }^{19,20)}$. 結晶 格子と分子の配列については1930年代から多くの結晶構 造の専門家によって解析されてきた。「日本ゴム協会 2014 年年次大会で「結晶ではないのでは?」という質問が出さ れたが，伸長結晶が「結晶」であることは1925年以来疑 問の余地はない.」

\subsection{1一軸引っ張り試験（Uniaxial deformation or sim- ple elongation)}

Gough も Katz も一軸伸長で伸長結晶を発見した。一軸 伸長 (単純伸長 Simple elongation) は大変形が可能であ るが, 変形過程で材料に生じている変化は伸長結晶だけで はない. 最初に, 変形に伴い発生する応力の実験データを 示す，通常は空気の温度が管理された恒温槽の中で引っ張 るが，溶媒を使って発熱温度の影響を少なくした実験を紹 介する。図 2 はIRの硫黄加硫ゴムの短冊状サンプルを, $29^{\circ} \mathrm{C}$ の溶媒中で, 歪み速度 $0.07 \mathrm{sec}^{-1}$ で引っ張ったStressstrain Curveを, 「最大引っ張り歪み」を変えて, 引っ張 り速度と同じ速度で収縮させている ${ }^{21,22)}$. Elongation ratioは伸び度 $(L / L o)$ で, 歪み $(L-L o) / L o$ にプス 1 をした值である。最大伸びを 5.5 以下で引っ張りを止め,

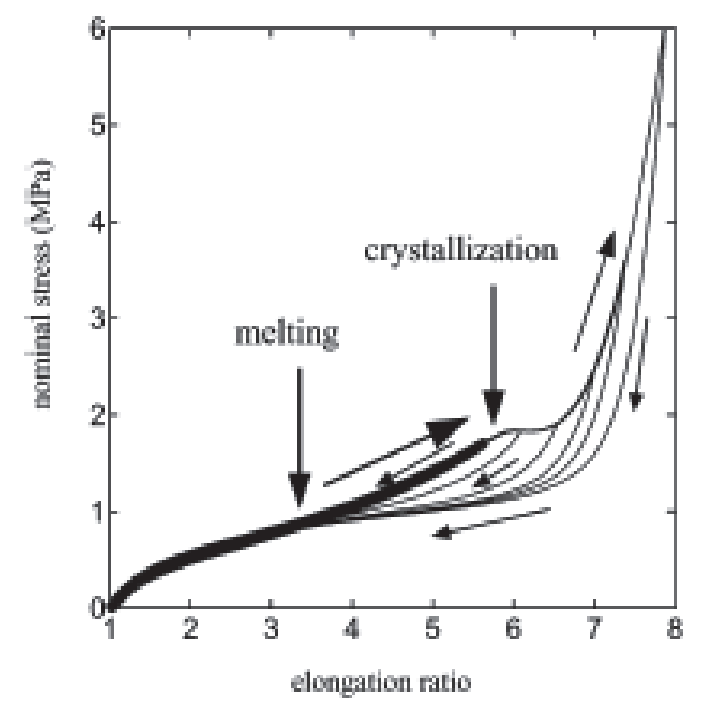

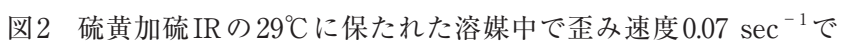
引っ張った時の応力と歪みの関係を最大歪みを変えて戻した時 の応力変化の履歴 ${ }^{21}$. Reprinted with permission from Macromolecules 2003, 36, 6462-6471. Copyright 2003 American Chemical Society. 


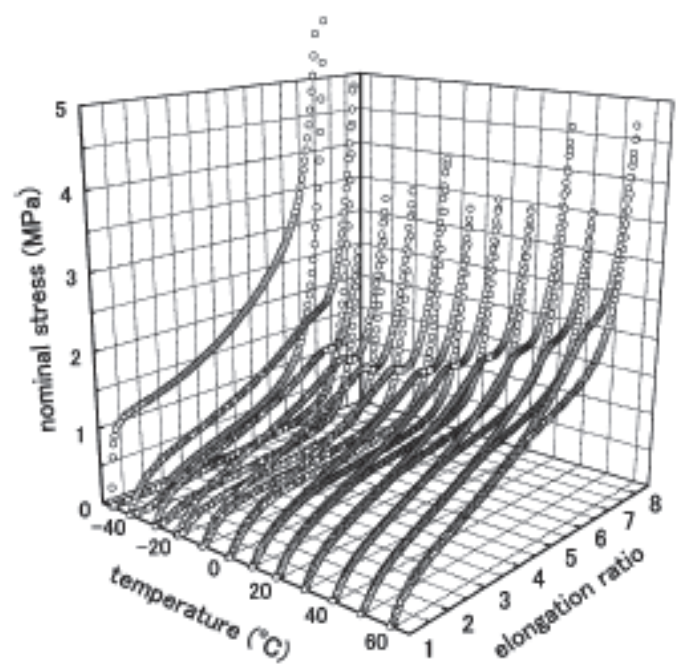

図3 硫黄加硫 IR の Stress-Strain Curve の温度依存性. 歪み速度は $0.07 \mathrm{SEC}^{-121)}$. Reprinted with permission from Macromolecules 2003, 36, 6462-6471. Copyright 2003 American Chemical Society.

収縮させると応力は引っ張り時と同じカーブを戻る．最大 伸びを 5.5 以上に引っ張ってから戻すと伸長時より低い応 力を示して戻る.この行きと戻りで異なるカーブをたどる ことをヒステレシスループ (履歴) と呼ぶ. ヒステレシス

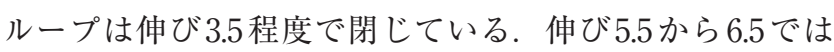
応力が上がらず， 6.5 までフラットで，そこから立ち上が ることに注目して頂きたい，著者らはX線測定を同時には していないが, 応力の低下が始まる伸び 5.5 から結晶化が

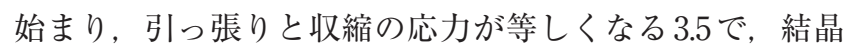
が完全に溶けると考えている，応力の立ち上がり (Stress-upturn or stress hardening) が始まる前に, 応力 を下げる（Stress-downturn or stress softening）要因が あるために，歪みの増大による応力増加とバランスして伸 び5.5 から 6.5 の歪みで応力はフラット（stress-flat）にな っている.

著者らは, 同様の引っ張り一収縮実験を広い温度範囲

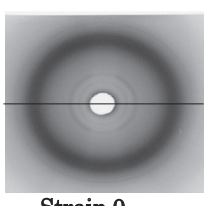

Strain 0

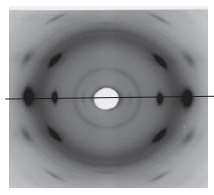

Strain 6.0

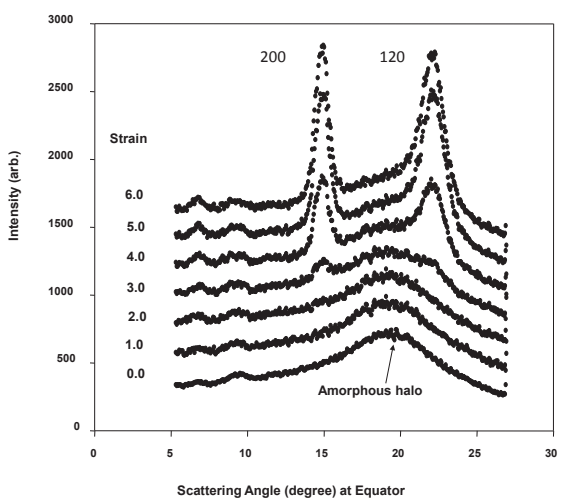

図4 WAXD写真（歪みゼロと歪み 6.0） と子午線方向の散乱強度の 散乱角度依存性を各歪みでのパターンを重ねた ${ }^{14)}$. Reprinted with permission from Macromolecules 2002, 35, 6578-6584. Copyright 2002 American Chemical Society.

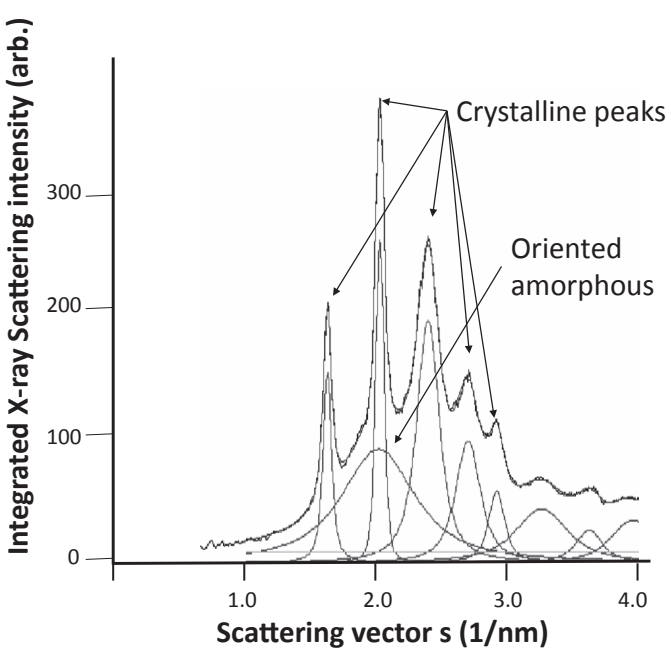

図5 変形前の無配向のアモルファスを差し引いた, 変形後の積分散 乱強度の散乱ベクトル $\mathrm{s}$ 依存性. 結晶ピークと幅広い「配向し たアモルファス」の散乱

$\left(-35^{\circ} \mathrm{C}\right.$ から $\left.+60^{\circ} \mathrm{C}\right)$, 歪み速度 $\left(0.07 \mathrm{sec}^{-1}\right)$ で実施した。 広い温度範囲で, Stress-flatが先行してからStress-upturn が起きている(図3). - 40ㄷ C゙は応力は下がることなく

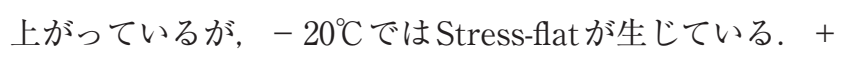
$60^{\circ} \mathrm{C}$ でも Stress-flatが生じてから Stress-upturnが見られ る.このグラフでは温度が上がっても（伸長結晶化が起こ りにくくなっても), 大変形での応力が下がっているよう には見えない。歪み速度依存性も興味深いがここでは略 す.

\subsection{WAXD写真の解析法}

伸長結晶のWAXD写真は歪みが大きくなるにつれて変 化する. 図 4 に加硫 NRの変形前と歪み 6.0 の写真を示す. 歪みゼロの写真に見られる円状の散乱はランダムに配向し ている分子のセグメントとセグメントの距離に対応してい る. 無定形（アモルファス）のセグメントーセグメント間 の距離は分散していて, ぼんやりした円状の散乱なのでハ ロー（halo）と呼ばれている。図4の右側に, 写真の子午 線方向のX線散乱強度の散乱角度 $(2 \theta)$ 依存性を示した. 歪み増大と共に, アモルファスハローが減少し, 結晶ピー クが出現してくる. 歪み 4.0 以上では子午線方向に結晶の 200 と 120 の面に対応したピークが現れる ${ }^{14)}$.

歪み6.0のWAXD写真から歪みゼロのWAXD 写真（無 配向のアモルファス）をサンプル厚みを考虑して差し引 き, X 線散乱強度を子午線方向だけでなく, 全ての方向に 積分した 1 次元の強度分布を図 5 に示す。これは配向した アモルファスと結晶からの散乱である. ピーク分離すると 結晶からのピークと配向したアモルファスの広い山が分離 できる。図4の歪み 6.0 の写真のアモルファスハローは方 位角依存性が少ない. 後に記述するが, これはNR, IRの 特徵で, BR, IIRでは方位角依存性が大きく, 配向したア モルファスの方が結晶成分よりずっと大きい. NR, IRで 

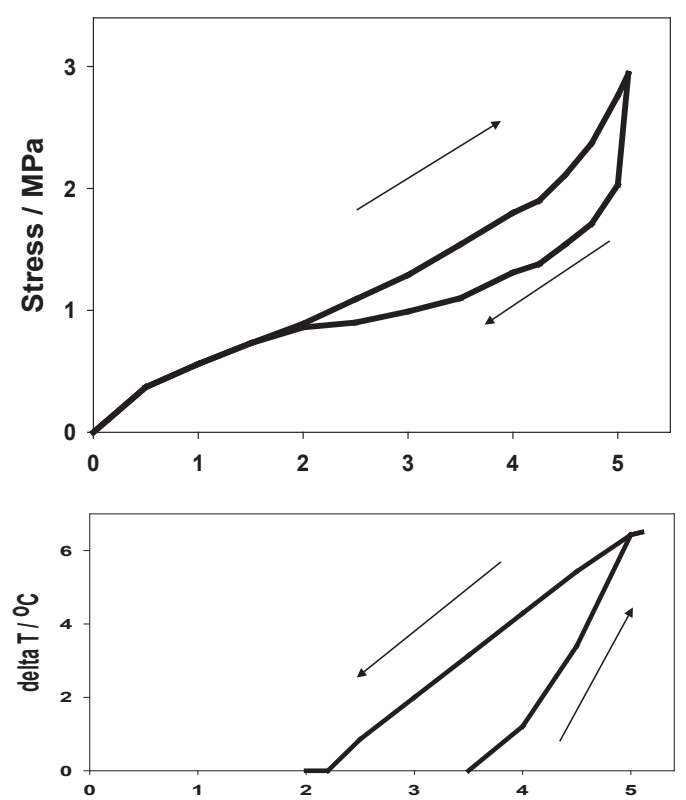

図6 硫黄加硫NRのStress-Strain Curve と表面温度変化. 室温で歪 み速度 $0.14 \mathrm{sec}^{-1}$

は，無配向のアモルファスが $70 \%$ 以上存在する．成分の 分離方法は 2002 年に我々のグループで始め，改良を続け てきた．他の研究グループは彼らの計算方法を改良してい る。細かい差はあるが結果には差が見られない，特に無配 向のアモルファスが70\%以上を占めることはどの研究グ ループも一致している．配向したアモルファスの量だけで はなく，配向量をや向きの方向依存性を考虑した新しい評 価法を工夫すべきではなからうか.

1.5 一軸伸長過程での温度变化, 体積变化, 網目切断.

\section{5.1 一軸伸長過程で生ずる温度変化.}

加硫NRを伸長すると結晶化によってサンプルの表面温 度が $10^{\circ} \mathrm{C}$ 近く上昇する ${ }^{23,24)}$ ．高焦点高性能赤外線温度計に より，変形と同時に表面温度の上昇を測定できる．図6の サンプルの表面温度は歪みが 3.5 に達してから上昇が始ま り，最大歪み 5.0 で $6.2^{\circ} \mathrm{C} に$ 達し，収縮させると温度は直線

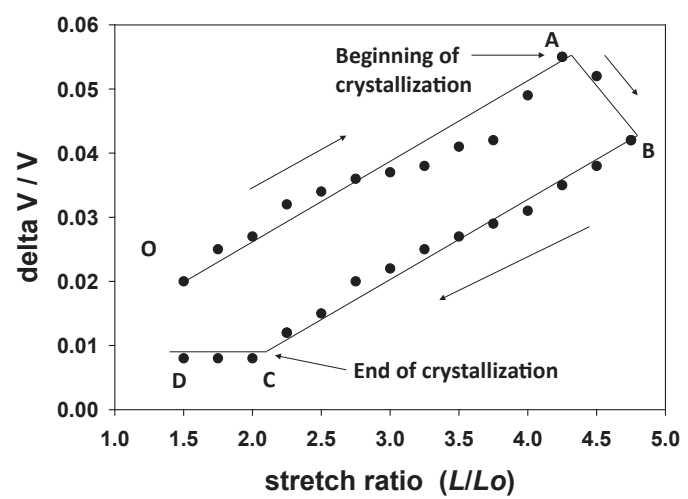

図7 比体積 $(\operatorname{deltaV} / \mathrm{V})$ の歪み依存性. 硫黄加硫 NR. 歪み速度 $0.02 \mathrm{sec}^{-1}$ at $23^{\circ} \mathrm{C}^{25)}$. Reprinted with permission from Macromolecules 2008, 41, 7579-7583. Copyright 2008 American Chemical Society.
的に低下している。図6の Stress-strain Curveも, 歪み 3.5 の近傍で勾配が変わって, 伸長結晶化が始まっている ので，結晶化による温度上昇は明らかである，ゴム弾性論 によれば，温度上昇は応力増加をもたらすはずであるが， 実験データはむしろ応力フラットの要因になっているよう に見える.1806年の Goughの実験から判明している温度 上昇の影響をどう解釈すべきか?

\subsection{2 変形過程で生じる体積変化，ボイド，クラックの 発生}

結晶の密度はアモルファスの密度より $10 \%$ 高いので, 伸長結晶が生じれば，密度が上がり，比体積は減少するは ずである。一方，ゴムが変形する時，ゴム中の結晶や粒子 は変形しないので, 応力と歪みが集中する点が必ず生じ, その点からクラックやボイドが発生すると, 体積は膨張し, 密度は下がる. サンプル表面にペイントを塗ってペイント の粒子の位置をミクロンオーダーで測定し， 2 点間の距離 から伸長による体積変化を測定した報告を図7に示す ${ }^{25}$. 比体積 (delta $V / V o)$ は変形の当初から増加し (O-A), 結晶化が始まると低下する（A-B），サンプルを収縮する （B-C-D）と比体積も減少する，C点で結晶が完全に溶けた と著者は考えている．伸長に伴う比体積増加はクラックや ボイドの発生であり, 収縮過程での比体積の減少はクラッ クボイドが縮小していき，伸長結晶は溶けて体積を増加す るはずだが寄与が小さいのであろう，C点で完全に結晶が 溶けたとして, C-Dでは体積変化がない理由は判らない。 CCD メラの解析精度の向上と統計処理によって, 変形 に伴う体積変化（密度変化）が, サンプル表面の位置デー 夕から得られる時代になった，追試を打願いしたい．

恒温槽内で一定歪みまで伸長して固定し, 体積変化と応 力を測定する実験は，伸長結晶化により比体積が減少する ので，伸長結晶の測定法として使われてきたが，静的な測 定であった．今後は伸長と共に変動する体積の動的な測定 に注力すべきであろう。

\subsection{3 伸長過程のラヂカル発生}

分子の破断, 網目の切断が生じると炭素ラヂカル, 水素 ラヂカルが発生する．硫黄加硫NRを一軸伸長させながら,

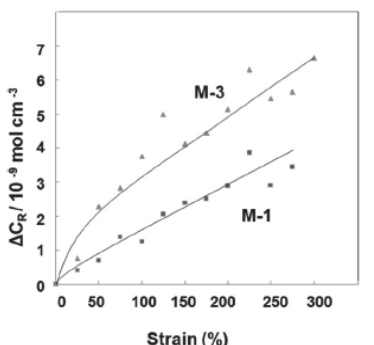

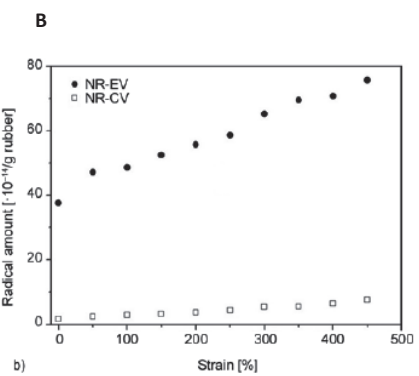

図8 伸長過程でのラヂカルの発生量. 25 度 C, 歪み速度 0.035 $\mathrm{sec}^{-1} \cdot \mathrm{A}^{.26)}$ Reprinted with permission from Polymer 52 (2011) , 2453. Copyright 2011 Elsevier Science Ltd. B: ${ }^{28)}$ 
ラヂカルの発生量をElectron Spin Resonance（ESR）を用 いて測定すると図 8 に示すように変形と共に増加する ${ }^{26,27)}$. 硫黄加硫では，硫黄原子が 1 個関与する架橋（モノ）と 2 個関与する，3個以上が関与するポリの 3 種があり，加硫 促進剤の選択により，3種の架橋を選択できる。モノが多 いと耐熱性が良く，ポリが多いと疲労に強いと知られてい る. 同じ網目密度でも, この比率によって物性が異なる。 図 8AではM-1がモノが多く, M-3 はポリが多い. モノが 多い方がラヂカルが多く発生する。 ポリの方が網目の柔軟 性が高く, 網目が切れる確率が低いらしい. 図8Bでは加 硫系による差が見られる。まだ網目全体とラヂカルが発生 した網目の割合が判っていないが, 網目の破断は小変形か ら起きていることが判ってきた．NRはIRよりラヂカルの 発生が多い. ESRによるラヂカルの測定については, 今 後の研究が期待される. 変形中に網目は破断しないと仮定 して, 理論は作られてきたが, 疑ってみる必要が生まれて きた。

\section{6 ゴム原材料の不均質 加硫による不均質.}

\subsection{1 原材料の不均質.}

合成ポリイソプレンは重合ミスにより生じたハードゲル を含む. 89 年の論文では $25 \%$ と書かれている，図 9 にハー ドゲルの電子顕微鏡写真を示す ${ }^{28)}$. ハードゲルを減らす製 造法の特許 ${ }^{29)}$ が最近でも申請されているので, 減少はし ていても数ミクロンの大きさのハードゲルを $2-10 \%$ を含 むであろう。但し，重合の専門家によると， cis 1，40付 加重合では 3 次元化の可能性はなく，ゲルではなく線形の 超高分子量成分が製造された可能性の方が高い ${ }^{30)}$ 。素練り によって，ハードゲルと呼ばれている異物は小さくなる が，無くなることはない. プラスチックと比べてみると， 最も安価なプラスチックであるポリオレフィンの不純物は 触媒残椬で通常 $0.02 \%$ 以下である。重合後の洗浄工程，パ ウダー化, ペレット化の工程でゲル状のものが問題になる ことはない. プラスチックを溶融固化する過程（紡糸工程 やフィルム押し出し工程）で歪みを与えられて Flow-induced crystallization（FIC）が生じ，シシケバブ構造が 生成すると考えられている。溶融したプラスチックは核生 成になる核剤が僅か（0.2\%以下）添加されている ${ }^{30)}$.

天然ゴムの場合は非ゴム成分がラテックスの $6 \%$ を占め る. 非ゴム成分は, 蛋白質, 炭水化物, ステアリン酸など

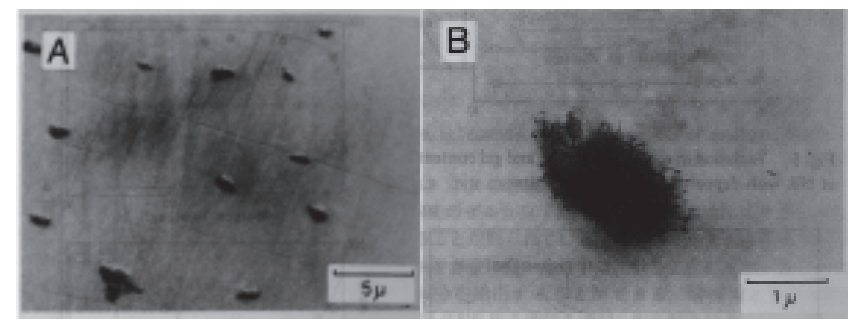

四9 合成ポリイソプレン (IR) 中のハードゲルの電子顕微鏡写真 ${ }^{28)}$.
A

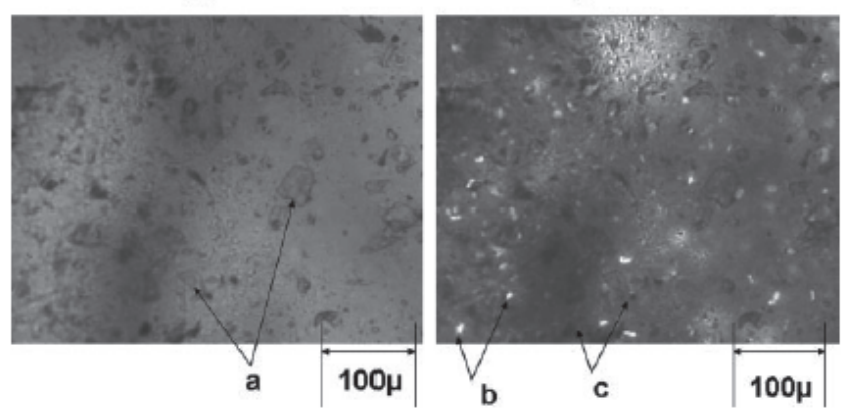

図 10 NR ラテックスの光学顕微鏡写真 $(\mathrm{A})$ と偏光顕微鏡写真 (B). $\mathrm{a}$ - 蛋白質の凝集体, b-Quebrachitol（糖）の結晶, c Phospholipid と fatty-acidのミセル ${ }^{31)}$. Reprinted with permission from J. Polym. Sci. Part B: Polym. Phys. 2008; 46: 2456. Copyright 2008 Wiley Periodicals, Inc.

で構成され，ゴムと化学結合しているわけではなく, 結晶 を作っていたり，ゴム分子を物理的に結び付けてゲル成分 を作っている. ラテックスをそのまま乾燥して, 光学顕微 鏡, 偏光顕微鏡で観察すると図 10 のように見える. クエ ビラキトール（糖）は結晶を作っており偏光顕微鏡で白く 光る. 蛋白質, リン酸, 脂肪酸も分離している ${ }^{31,32)}$. NR ラテックスは通常分子量を下げるために素練りする, 上記 の固形物は小さくなり, 光学顕微鏡では確認できなくなる が消滅するわけではない.

\subsection{2 加硫による不均質.}

硫黄加硫では亜鉛華もステアリン酸も触媒として働く助 剂なので, 加硫後もそのまま残っている. 加硫後の WAXD写真には亜鉛華とステアリン酸の結晶が, リング として映る (図 11） ${ }^{31)}$ 。亜鉛華を 3 部以上入れると結晶の 3 本のリングが見られる. ステアリン酸の結晶も内側に 3 本のリングを示す。変形過程でステアリン酸の結晶が配向 するので，ミクロな歪みの指標として伸長結晶の解析に使 う試みが1940年代から研究されてきたが, 歪みと比例す る範囲が限られているので, 現在は使われていない。一 方，亜鉛華の結晶のリングには配向が見られず，ゴムの変 形と共に向きを変えない. ステアリン酸はゴム分子と何ら かの結合をもっていると推測される. 小角中性子散乱では亜 鉛華の周りに, 濃密な網目が存在しているとされている ${ }^{33)}$. パーオキサイド加硫の場合はパーオキサイドが固体状態で 混ざり，溶けてからゴムの二重結合と反応する．分散する 前に溶けてしまうと，ゴムの中に入れず均質に分散するの は難しい. 硫黄加硫とパーオキサイド加硫のどちらが均質 な網目を作っているか? 議論されている. 中性子散乱を使 った研究では空間的な不均質性が硫黄加硫の方が高い ${ }^{33)}$. 分子運動性を測定する Multiple Quantum NMR の測定で はパーオキサイド加硫の方が不均質性が高いと報告されて いる ${ }^{34)}$.

不均質な分布の網目と固体粒子の存在は応力と歪みの集 中点を生じる.この点で伸長結晶が生じるか, クレーズま 


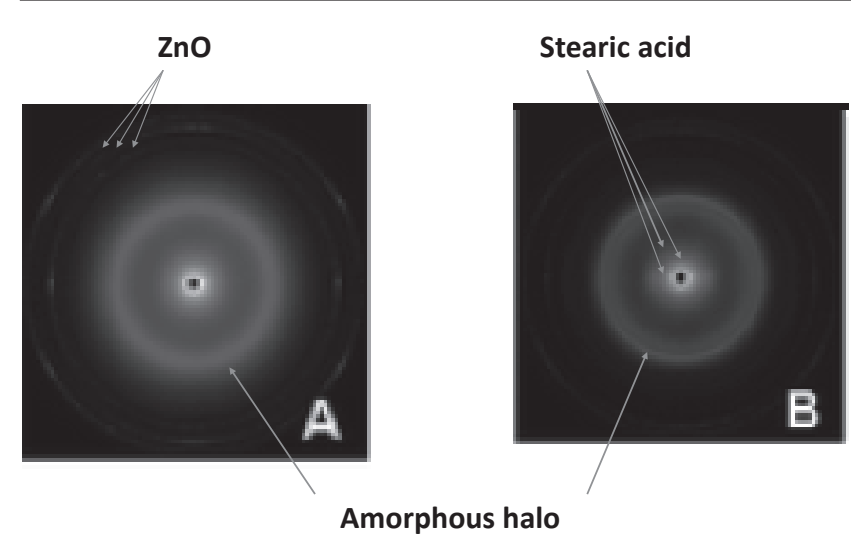

図11 ゴム中の亜鉛華の結晶からのWAXD散乱（A）外側に 3 本と ステアリン酸結晶からのWAXD散乱（B）内側にに 3 本．両 者の間にゴム分子のアモッルファスハローが存在.

たはボイドが生まれると，その表面で伸長結晶が始まる. 伸長結晶化が応力を下げ，クレーズの進展を止める。この メカニズムが破断を防ぐのではなかろうか. 破断伸びが大 きくなり，結果として破断強度が大きくなる.

\section{7 第一講のまとめ}

(1).一軸伸長の変形過程で, 伸長結晶化だけが生じるわけ ではない，変形の開始と共にラヂカルが増え（網目の破断 が生じ), クラック，ボイドなどの cavitation が発生して 比体積はむしろ増える，伸長結晶化が始まると発熱して温 度が上がる。網目点間の分子は伸び切り限度に近づく。

(2). 伸長結晶化の開始と共にStress-strain Curveは勾配を 下げ，その後応力上昇が観測される。伸長結晶化により温 度が上昇するが, stress-hardening は観測されていない。 (3). 分子の配向が生じてから結晶化が始まるが，破断近く の大変形になっても，無配向のアモルファスがNR，IRで は70\%以上残る.NR，IRの場合配向したアモルファスは, 結晶に変化する.

(4). 伸長結晶化はゴムを大変形にするだけで生成する，未 加硫の合成ポリイソプレンに $0^{\circ} \mathrm{C}$ 以下で大変形を与えれば 伸長結晶化する，だから，網目も，加硫剂も，非ゴム成分 も伸長結晶化に必要ではない. 特別な核剤は要らない.

(5).ゴム材料の不均質性はプラスチックとは異なるレベル である，原材料である合成ゴム，天然ゴムは不純物をなく す洗浄工程を殆どもたず，機械的な練りによって不純物の 粒子サイズを小さくしている，ゴム分子の運動性は気体か 液体のレベルであるのに，固体粒子だけでなく，より硬い 結晶が分散している。

（6. 網目の不均質な分布と非ゴム成分の存在が応力または 歪みの集中する点を必ず生じるであろう。この点から伸長 結晶化が始まり，応力を下げる。この点がクレーズまたは ボイドを作ると，その表面で伸長結晶化が始まり，応力を 下げる。このプロセスが破断を防ぎ，破断伸び，破断強 度，引き裂き強度を上げるのではなかろうか。

\section{References}

1 ) Gough, J.: John Gough and his Observation of Rubber Thermodynamics. Through Internet

2 ) Flory, P. J.: Principles of polymer chemistry. Chapter 11. Rubber elasticity. Cornell University Press (1953)

3 ) Treloar, L. R. G.: The physics of rubber elasticity ( $3^{\text {rd }}$ Ed.) Chapter 6-9. Possible influence of crystallization. Page 124. Oxford University Press, (1975)

4 ) Erman, B.; Mark, J. E.: Structures and properties of rubberlike networks. Oxford University press, 1997

$5)$ Saito, N.: Physics of polymer. Shoukabou (1955)

6 ) Kubo, R.: Rubber elasticity. Shoukabou reprinted in 1996.

7 ) Kohjiya, S., Ikeda, K. eds.: Chemistry, Manufacture and Applications of Natural Rubber, Woodhead / Elesvier, Cambridge 2014, Chapter 5. Toki, S.: Strain-induced crystallization and mechanical properties of rubber.

8 ) Katz, J. R.: Die Naturwissenschaften 13, 410 (1925).

9 ) Clark G. L.; Gross S. T.: Smith W. H.: Journal of Research of the National Bureau of Standards, 23, July 1939, 1.

10) Mitchell, G. R.: Polymer, 25, 1563 (1984).

11) Toki, S.; Fujimaki, T.; Okuyama, M.: Polymer, 41, 5423 (14) (2000)

12) Toki, S., Fujimaki, T.: Nippon Gomu Kyokaishi 75, 93 (2002)

13) Murakami, S.; Senoo, K.; Toki, S.; Kohjiya, S.: Polymer 43, 2117 (2002)

14） Toki, S.; Sics, I.; Ran, S.; Liu, L.; Hsiao, S. B,; Murakami, S.; Tosaka, M.; Senoo, K.; Kohjiya, S.: Macromolecules 35, 6578 (2002).

15) Trabelsi, S.; Albouy, P. A.; Rault, J.: Macromolecules, 36, 7624, (2003)

16) Toki, S.:: Nippon Gomu Kyoukaishi 79, 472 (2006)

17) Tosaka, M.; Senoo, K.; Sato, K.; Noda, M.; Ohta, N.: Polymer, 53 , 864 (2012)

18) Mitchell, J. C.; Meier, D. J.: J. Polymer Science, part A-2, 6, (1968), 1689-1703

19) Che, J.; Burger, C.; Toki, S.; Rong, L.; Hsiao, B. S.; Amnuaypornsri, A.; Nimpaiboon, A.; Sakdapipanich, J.: Macromolecules, 2013, 45, 4520-4528.

20) Che, J.; Burger, C.; Toki, S.; Rong, L.; Hsiao, B. S.; Amnuaypornsri, A.; Nimpaiboon, A.; Sakdapipanich, J.: Macromolecules, 2013, 45, 9712-9721

21) Miyamoto, Y.; Yamao, H.; Sekimoto, K.: Macromolecules, 36 (2003), 6462-6471

22) Miyamoto, Y.: Nippon Gomu Kyokaishi, 77, 12 (2004)

23) Dart, S. L.; Anthony, R. L.; Guth, E.: Ind. Eng. Chem. 34 (1942) 1340

24) Candau, N.; Lagmach, B.; Chazeau, L.; Chenal, J-M.; Gathier, C.; Biben, T.; Munch. E.: European Polym. J. 64 (2015) 244-252

25) Le Cam, J. B.; Toussaint., E.: Macromolecules, 2008, 41, pp.75797583.

26) Toki, S.; Takagi, R.; Ito, M.; Hsiao, B. S.: Polymer 52 (2011), 2453

27) Posadas, P.; Malmierca, M. A.; Gonzalez-Jimenez, A.; Ibarra, L.; Rodriguez, A.; Valentin, J. L.; Nagaoka, T.; Yajima, H.; Toki, S.; Che, J.; Rong, L.; Hsiao, S. B.: eXPRESS Polymer Letters 10, (2016), 2-14.

28) ShiiBashi, T.; Hirose, K.; Tagata, N.: Koubunshi Ronbunshuu 46 (8), 465-472 (Aug.1989)

29) Japanese Patent: JP 2015-205960 A 2015.11.19

30) Ueki, S., Imai. M., Matsumura. T.: Private communications

31) Toki, S.; Burger, C.; Hsiao, B. S.; Amnuaypornsri, S.; Sakdapipanich, J.; Tanaka, Y.: J. Polym. Sci. Part B: Polym. Phys. 2008; 46: 2456

32) Toki, S.: Nippon Gomu Kyoukaishi, 83, 37 (2010) 
33) Ikeda, Y.; Higashitani, N.; Hijikata, K.; Kokubo, Y.; Morita, Y.; Shibayama, M.; Osaka, N.; Suzuki, T.; Endo, H;, Kohjiya, S.: Macromolecules (2009), 42 (7), 2741-274

34) Valentin, J. L.; Posadas, P.; Fernandez-Torres, A.; Gonzalez, L.; Chasse, W.; Saalwachter, K.: Macromolecules, 2010, 43 (9), 4210-4222

\section{日本語文献}

2）P. J. フローリ著：岡小天，金丸競 共訳「高分子化学」丸善， 昭和 31 年
5 ) 斉藤信彦. 高分子物理学 裳華房 昭和 33 年

6 ）久保亮五「ゴム弾性」裳華房 復刻版 1996 年

12）土岐重之, 藤卷達雄 : 日本ゴム協会誌，75，93（2002）

16）土岐重之：日本ゴム協会誌，79（10），472（2006）

22）宮本嘉久：日本ゴム協会誌， 77，12（2004）

28）推橋 透, 広瀬和正, 田形信雄：高分子論文集 46 (8)，465-472 (Aug.1989)

29）日本特許. ポリイソプレンの製造法（JP 2015-205960 A 2015.11.19)

32）土岐重之：日本ゴム協会誌，83（10）37（2010） 